\title{
A comparative Study of Achievement in Mathematics at Secondary level in Navodaya Vidyalaya
}

\author{
Dr .Jai Shankar Prasad Yadav \\ M.Sc., M.Ed.,Ph.D.(Education) \\ J.N.V. Wafapursharma, P.O:-Sirsabiran, District-Vaishali, 844123
}

\begin{abstract}
Achievement in any subject seems to be common problem that means what student has learnt in a school subject. It is generally measured on set of question which the student has to respond .Thus the tool for measuring achievements test item. The correct responses are understood in number which is called scores; these scores constitute achiever in a subject. The word achievement means performing successes fully or things have done successfully, especially with efforts and skills. Achievement may be measured through formative evaluation or summative evaluation. Of course achievement play important role of all kind of education. Mathematics is the backbones all sciences and its effect have rather percolated to other non-scientific discipline .Scientific advancement, use of modern technology in day to day life; globalization and modernization tremendously change the mindset of people and student.
\end{abstract}

\section{Introduction}

The term achievement means the act of achieving or performing accomplishment, especially using their own effort and skill; every teacher of mathematics needs to be informed and convinced about the educational value of his subject, its educational soundness must be made clear to his at the very outset. A comparative study of achievement in Maths have a project focus upon prefect work with in the class room milieu and result analysis of class X Board result J.N.V.Vaishali Bihar and J.N.V .Bagudi, Balasore Orissa of secondary level mathematics. With reference to the fast changing school education Scenario in the country ,the Jawahar Navodaya Vidyalaya have established a reputation for their academic achievement and other activities related to the holistic development of the personality of the children. Achievement test in mathematics have compared to the position in other disciplines ;more test have been constructed in Mathematics, including arithmetic's ,algebra, geometry and trigonometry .Some investigator like Aram etal(1957),Maniar(1961),Dash (1967) ,Misra(1970),Rajput ,A.S (1984) Singh(1986) found attitudes to be related to mathematics achievement; cause under and low achievement in mathematics vary from defective text book to some personality needs .Attitude towards Maths does affect achievement in Mathematics .Md. Miyan (1982) constructed a test of Mathematical creativity for Students of class IX which includes abilities, to analyse, determine patterns; likeness, difference and application. Yadav.P.S (1984) studied "Effect of Mastery learning strategy on Pupils Achievement in Mathematics, their self concept and attitude towards Mathematics" and finding that the achievement distribution curves in case of gain scores of experimental and control group were compared, it was found that the curve in the case of the control group extended to the negative side and $d$ id not show positive sign. After the experimental treatment of the experimental group of pupils evinced have a more positive attitude towards mathematics. When the researcher compared national survey results in 1993 and 2000 of MAA they found that "the use of Computer Science lesson is striking in its lack of change. Even in 2000, less than $10 \%$ of Science and Maths lessons included students using computer.

Role of achievement:-Educational achievement is process of estimating or evaluating and apprising the degree and dimension of students further; it is also a process of estimating and appraising the proficiency level of the particular educational practice as a achievements. The primary purposes of achievements have to monitor the students learning to constituted and objective, check both progress and ultimate's achievements so that suitable remedial may be instituted. Academic achievement test are conducted at the end of unit or course to know how well a learner has learned during the program of study and first category achievement test or progressive tests are generally conducted after the completion of the syllabus according to performance whether the student promoted to the next class or not but in Navdaya $100 \%$ might be promoted in consequently. These test provide feedback not only to the student but also to the teacher. They help the teacher to modify or improve the teaching learning style for further quality as well as quantity result. We have to discuss the achievement level of the student in marks of two vidyalayas one of them Orissa and Bihar.

\section{Objectives of the study}

1. To know the achievement level of student in Marks and creative abilities.

2. To examine the relationship of achievement in between two schools results. 


\section{Methodology}

Sample:- There are twenty nine states in India besides the seven union territories. The study planned to select two Schools from any two located in all over India; Presently 595(576+19**) Navodaya Vidyalayas runs smoothly and covering 27 States 7 union territories of the country excluding the state of Tamil Nadu. For this two Vidyalayas selected randomly by small piece of paper in which name was written there ; thus i study on the basics of following criteria:- (1)Their assurance of suitable test administration and cooperation by the Navodaya Vidyalaya teacher`s and esteemed Principal Sri Mahendra Prasad, Sri .S.K.Saha,Md.Amanullah.(2)Navodya school's are co-educational as well as residential (3) Vaishali and Balasore School's being located in rural area.

(i) Navodaya teacher's support willingness in administering frequent test and evaluating the answer sheet as per the instruction given by the investigator.

(ii) The investigator had to visit regularly for the academic session 95-96,96-97,97-98,98-99, 1999-2000 to find out whether the teacher had finished teaching the particular unit to fix up the test date hand over the question papers, to collect the answer sheet from the teacher and to give them back to the student after noting down the required data.This to done for each test and central Board of secondary education of class $\mathrm{X}$ final result and pre-board test in Mathematics.

(iii) It would be not possible to study such a large sample all by oneself only study here J.N.V. Vaishali, during the session of $1999-2000$ get better result $97.22 \%$ and category wise status as below:-

(iv) Statistical treatment:-

The statistical treatment initiative here Mean, Medians' were calculated for this study.

Table-1

\begin{tabular}{lllll}
\hline Boys & Girls & Rural & Urban & Total \\
\hline $\mathbf{2 6 5}$ & 165 & 323 & 107 & 430 \\
\hline
\end{tabular}

In above table 36 appeared in CBSE Board exam in mathematics and passed only 35.

Result analysis of class X mathematics (1999-2000)

Table -2

\begin{tabular}{|c|c|c|c|c|}
\hline Class Interval & Class Mark( $\left.\mathbf{x}_{\mathbf{i}}\right)$ & Frequency(fi) & Cumulative frequency & $\mathbf{x}_{\mathrm{i} .} \mathbf{f i}$ \\
\hline $0-20$ & 10 & 01 & 01 & 10 \\
\hline $20-40$ & 30 & 03 & 04 & 90 \\
\hline $40-60$ & 50 & 13 & 17 & 650 \\
\hline $60-80$ & 70 & 10 & 27 & 700 \\
\hline \multirow[t]{2}{*}{ 80-100 } & 90 & 08 & 35 & 720 \\
\hline & & $\sum \mathrm{fi}=35$ & & $\sum x_{i .} F i=2170$ \\
\hline
\end{tabular}

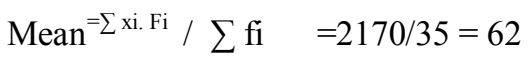

Table-3

CBSE result of class $X_{A}$ and $X_{B}$ J.N.V. Balasore Orissa 1995-1996

\begin{tabular}{lllll}
\hline Class Interval & Class $\operatorname{Mark}\left(\mathbf{x}_{\mathbf{i}}\right)$ & Frequency(fi) & $\begin{array}{l}\text { Cumulative } \\
\text { frequency }\end{array}$ & $\mathbf{x}_{\mathbf{i} .} \mathbf{f i}$ \\
\hline $\mathbf{0 - 2 0}$ & & & 01 & 10 \\
$\mathbf{2 0 - 4 0}$ & 10 & 01 & 04 & 90 \\
$\mathbf{4 0 - 6 0}$ & 30 & 03 & 27 & 1150 \\
$\mathbf{6 0 - 8 0}$ & 50 & 23 & 35 & 560 \\
$\mathbf{8 0 - 1 0 0}$ & 70 & 08 & 55 & 1800 \\
& 90 & 20 & & $\sum \mathrm{x}_{\mathrm{i}} . \mathrm{f}_{\mathrm{i}}=3610$ \\
\hline
\end{tabular}

Mean $=\sum \mathrm{x}_{\mathrm{i}} \cdot \mathrm{f}_{\mathrm{i}} / \sum \mathrm{f}_{\mathrm{i}}=3610 / 55=65.63$

\section{Comparative achievement}

Difference in between J.N.V .Balsore Orissa and J.N.V. Vashali Bihar get 2.62, Balasore was the higher achiever in respect of Vaishali but latter on Vaishali was too much improved in mathematics result shows in table -4 . 


\section{Table-4}

Result analysis of A.I.S.S.C.E. Examination 2000

\begin{tabular}{|l|l|l|l|l|l|l|l|l|}
\hline Name & Appeared & Pass & compartment & Fail & $\begin{array}{l}\text { Pass } \\
\% \\
2000\end{array}$ & $\begin{array}{l}\text { Pass } \\
\% \\
1999\end{array}$ & $\begin{array}{l}\text { Pass } \\
\% \\
1998\end{array}$ & Remark \\
\hline Vaishali & 65 & 63 & 2 & 0 & 96.92 & 91.03 & 71.10 & $\begin{array}{l}\text { Topper result in NVS RO } \\
\text { Patna(out of 23 } \\
\text { vidyalaya) }\end{array}$ \\
\hline
\end{tabular}

Table-4 clearly shows that mathematics teacher of Navodaya vidyalaya always try to given more emphasis to qualitative and quantitative result for fill up educational goals of JNVs founded on the philosophy of the Navodaya vidyalaya samiti researched by devoted and dedicated teachers.

\section{Conclusion}

*The majority of the student had favourable attitude towards mathematics.

*All the students in the sample have excellent observation skills compare to questioning skills.

* Students have good achievement scores in mathematics.

* Girls have slightly better achievement and attitude towards mathematics in JNVs.

\section{References}

[1]. Annual Report 1994-1995,96-97,98-99,1999-2000,NVS New Delhi.

[2]. Buch, M.B (1991), Chief Editor, Fourth Survey of Research in Education, 1983-1988, Volume - I, II, Page No 693-695, 845,874, 1044, N.C.E.R.T., New Delhi.

[3]. Raju. T.J.M.S(2012) :IJPE Patna(ISSN: 0378 -1003) Vol-43(2) Page No131-135 Publisher: HIBS $41-42$ Hardeep Enclave, Sikandra ,Agra 282007.

[4]. Saikia L.R and Chutia Manju (2013) : IJPE Patna (ISSN: 0378 -1003) Vol-44(1) Page No 5-7 Publisher: HIBS 41-42 Hardeep Enclave, Sikandra ,Agra 282007.

[5]. Saikia L.R and Kalita Sima (2013) : IJPE Patna (ISSN: 0378 -1003) Vol-44(2) Page No 116-118 Publisher: HIBS 41-42 Hardeep Enclave, Sikandra ,Agra 282007

[6]. Singh Lal Shaheb: Measurement Evaluation and statistics of education

[7]. Yadav .J.S.P (2001) A comparative study of achievement in Mathematics at secondary level in Jawahar Navoday Vidyalaya Vaishali (Bihar) and Jawahar Navodaya Vidayalaya Balasore Orissa . M.Ed, Disseration,N.O.U

[8] Yadav JSP(2011) status of maths lab:an evaluative study Ph.D. thesis PU Bihar 